Edyta BARAŃSKA

Uniwersytet Marii Curie-Skłodowskiej, Lublin

\title{
„Ona nie była jedną z nas"1. Wokół „feminizmu” Hannah Arendt
}

\section{Wstęp}

$\mathrm{T}$ eoria feministyczna wykazuje pewną tendencję polegającą na ignorowaniu lub uznawaniu za bezwartościowe tych koncepcji filozoficznych, których autorzy - kobiety nie przyznają otwarcie: „tak jestem feministką"2. Maria Markus nazywa ten wymóg samookreślenia się przez kobietę „żądaniem lojalności”. Jeśli brak jest takiej postawy u konkretnej autorki, to jej teorię uznaje się za bezwartościową, czyli niemającą nic sensownego do powiedzenia, lub też (w myśl zasady: nie jesteś $z$ nami to jesteś przeciwko nam) oskarża się ją o próbę ,wślizgnięcia się do męskiego klubu". Jej teoria jest wówczas niczym więcej jak popieraniem tradycyjnego obrazu kobiety, a co za tym idzie, zgodą na jej poniżanie. Do takich autorów - kobiet ignorowanych przez feministki należy Hannah Arendt. Przez bardzo długi czas była to postać pomijana w debacie feministycznej w ogóle, a wzrost zainteresowania się jej teorią sprowadzał się głównie do ostrej krytyki. W koncepcji polityki Arendt feministki dostrzegają chęć utrwalenia obrazu kobiety zdominowanej przez mężczyznę, kobiety, dla której idealnym miejscem do życia jest dom.

Głównym podłożem krytyki skierowanej w stronę Arendt jest podział świata. Autorka Kondycji ludzkiej ${ }^{3}$ wyróżnia dwie płaszczyzny życia

1 E. Young-Bruehl wyraża opinię feministek na temat Hannah Arendt. Zob. E. Joung-Bruehl, Hannah Arendt among Feminists, w: Hannah Arendt. Twenty Years Later, red. L. May, J. Kohn, The MIT Press, Cambridge-Massachusetts-London-England 1996, s. 322.

2 M. Markus, The 'anti-feminism' of Hannah Arendt, w: Hannah Arendt. Thinking, Judging, Freedom, red. G. T. Kaplan, C. S. Kessler, ALLEN \& UNWIN, Wellington-London-Boston 1989, s. 119.

Arendt charakteryzuje te dwie przestrzenie w Kondycji ludzkiej. (Zob. H. Arendt, Kondycja ludzka, tłum. A. Łagodzka, Wyd. ALETHEIA, Warszawa 2000, s. 27-86). W teorii Arendt człowiek żyje na dwóch płaszczyznach: prywatnej i pu- 
człowieka: sferę prywatną i sferę publiczną, z których tylko ta druga jest prawdziwie ludzką przestrzenią. Pierwsza istnieje tylko dla niej, jest od niej ,gorsza”, gdyż w przestrzeni prywatnej chodzi o przetrwanie. Polityka pozwala osiągnąć szczęście, nie życie prywatne. Dzięki niej człowiek jest naprawdę ludzki. Podczas, gdy w przestrzeni prywatnej ludzie „zachowują się", w sferze publicznej działają. Według Arendt polityka jest działaniem, a jej istnienie jest uzależnione od istnienia granicy pomiędzy tymi dwoma sferami, takiej samej, jaka istniała w starożytnym polis.

Dualizm ludzkiej egzystencji i potrzeba zachowania rozdziału między dwoma sposobami ludzkiego życia, która w teorii Arendt, przybiera

blicznej. Sfera prywatna istnieje jednak tylko ze względu na życie publiczne. Jest, można powiedzieć, kartą wstępu, do sfery publicznej. Jest więc tą ,gorszą" przestrzenią. Sprowadza się bowiem do utrzymania biologicznego życia. Arendt określa tę sferę jako ciemną stronąż̇ycia. Podział ów Arendt zapożycza od Greków. Pisze ona: dla starożytnych mieszkańców polis „,było rzeczą oczywista, że podtrzymanie indywidualnego życia winno być zadaniem mężczyzny, a przetrwanie gatunku zadaniem kobiet, $i$ obie te naturalne funkcje, praca mężczyzny związana $z$ dostarczaniem pożywienia i praca kobiety rodzącej dzieci, były podporządkowane temu samemu naciskowi życia. Naturalna wspólnota w gospodarstwie domowym rodziła się zatem z konieczności i konieczność władała wszystkimi wykonywanymi w niej czynnościami" (ibidem, s. 36). Arendt odwołuje się również do pism Arystotelesa. „Życie jest działaniem, a nie stwarzaniem", pisze on. (Arystoteles, Polityka z dodaniem pseudo-arystotelesowskiej ekonomiki, thum. L. Piotrowicz, PWN, 1964, s. 11 [1254a]). Stagiryta jest tym filozofem, który docenia rolę polityki. Stwierdza również, że człowiek jest zwierzęciem politycznym - homo politicus (ibidem, s. 6-7 [1253]), dlatego właśnie Arendt przywołuje jego poglądy. Arystoteles jednak za polityka nie uznaje kobiety. Gdy mówi o człowieku ma na myśli mężczyznę. Kobieta, dzieci i niewolnicy to mienie człowieka. Kobieta jest przeznaczona jedynie do roli matki. Nie potrafi działać. „Mężczyzna bowiem z natury jest więcej uzdolniony do władania aniżeli kobieta" (ibidem, s. 30 [1259b]). Arystoteles thumaczy więc taki stan rzeczy naturą ludzką. , Inaczej przedstawia się władza wolnego nad niewolnikiem, a inaczej mężczyzny nad kobietą, czy ojca nad synem. U nich wszystkich występuje składnik psychiczny, jednakowoż z pewnymi różnicami. Niewolnik bowiem nie posiada w ogóle zdolności do rozważania, kobieta posiada ją wprawdzie, ale niezbyt kompetentną" (ibidem, s. 34 [1260a]). W opinii Greków mężczyzny trud można zastąpić pracą niewolnika, ale trud kobiety rodzenie dzieci jest niezastępowalnym. Dlatego kobieta nie zdoła nigdy wydostać się z domu. Taka jest jej natura. Arendt jednak, gdy przywołuje pisma Stagiryty, nie odwołuje się do jego poglądów na temat roli kobiet. Istotny jest dla niej sam podział i fakt, że sfera prywatna dąży do zaspakajania potrzeb ciała, natomiast sfera publiczna - polityka, jest przestrzenią działania. To tutaj człowiek może osiagnąć szczęście. Polityka jest działaniem. Prawdziwe życie polega na działaniu. Arendt politykę określa mianem polis. 
wręcz postać aksjomatu, staje się pretekstem do ostrej krytyki pod adresem autorki Kondycji.

Celem moich rozważań jest udowodnienie, że Arendt nie była ani feministką, ani anty-feministką. Jej teoria polityki nie podejmuje problemu płci w ogóle. Polityka, w jej ujęciu, jest bowiem poza podziałem na mężczyznę i kobietę.

Niniejszy tekst podzielony został na trzy części. W pierwszej przedstawiam te poglądy, które ujmują Arendt jako autorkę feministyczną, choć jest ich znacznie mniej niż tych, które „oskarżają” autorkę Kondycji o anty-feminizm. W drugiej części przedstawię właśnie te koncepcje, które w teorii Arendt dostrzegają tendencje anty-feministyczne. W trzeciej części artykułu postaram się odpowiedzieć na pytanie: dlaczego Arendt nie jest ani feministka, ani anty-feministką.

\section{Arendt jako feministka}

Kiedy upłynęły wczesne lata siedemdziesiąte amerykańskie feministki, pisze Young-Bruehl, rozpoczęły celebrację czegoś co określa się mianem kobiecej cnoty ${ }^{4}$. W centrum zainteresowań znalazł się wówczas arendtowski podział na prywatne i publiczne. Feminizm ten nie odrzucił jednak dychotomii świata, lecz po prostu uznał sferę prywatną za lepszą od publicznej. Zaakceptował dualizm rzeczywistości i przypisał kobiete do przestrzeni prywatnej uznając ją za lepszą od męskiej - publicznej. Cnota kobieca, czyli coś w rodzaju emocjonalnego bogactwa, z perspektywy feminizmu, stanowiła wartość najwyższą. Triumf tej cnoty oznaczał tutaj zwycięstwo kobiet, a udział w polityce, która była przecież tą gorszą sferą, bo męską, nie miał znaczenia. Chodziło o to, by pokazać swoją wyższość jako kobiety właśnie. Owa kobiecość miała stać się narzędziem wyzwolenia. Rewolucję polityczną miała więc zastąpić rewolucja kulturowa. Nie chodziło jednak o uczestnictwo w polityce, ale o uznanie sfery polityki za gorszą przestrzeń egzystencji człowieka. W tym sensie Arendt zostaje, w pewien sposób, doceniona przez feministki, dlatego że nie odrzucają one dualizmu egzystencji, co, jak zobaczymy, zdarza się wśród feministek dość często. Poza tym Arendt jest postrzegana jako ta, która w pewien sposób rozumie sytuację kobiet. W połowie lat osiemdziesiątych, pisze

4 E. Young-Bruehl wymienia kilka faz w interpretacji teorii Arendt. E. Joung-Bruehl, Hannah..., s. 307-324. 
Young-Bruegel, kolejna generacja teoretyczek feminizmu na nowo odczytuje koncepcje Niemki. Twierdzą one, że choć Arendt nie rozważa sytuacji kobiet wprost, to z pewnością rozumie ona sytuację ludzi, którym odmówiono udziału w polityce. Korzenie totalitaryzmu ${ }^{5}$, w których autorka opisuje antysemityzm, są tego dowodem. Ważne jest dla nich również to, że Arendt sama była Żydówką, więc rozumie ona ludzi, którym odmówiono podstawowych praw. (Jednak, co Young-Bruehl również podkreśla, „bycie Żydówką” nie miało dla Arendt istotnego znaczenia) ${ }^{6}$.

Autorka Kondycji ludzkiej doceniana jest także pośród drugiej, młodszej generacji feministek. Główny problem stanowi wówczas pornografia. W rezultacie dochodzi do podziału w obrębie ruchu feministycznego na tych, którzy sprzeciwiają się pornografii, i tym samym, przyzwalają na interwencję w przestrzeń prywatną oraz na tych, dla których prywatność jest święta, którzy odrzucają możliwość politycznych regulacji tej sfery. Podział Arendt, w tym przypadku, staje na straży prywatności. Teoria Arendt zostaje więc odczytana przez feminizm pozytywnie. Jej dychotomia świata jest bowiem akceptowana, a wręcz postulowana przez tę odmianę feminizmu, która nie uznaje interwencji w prywatność.

Podobnie jest w przypadku jeszcze młodszej, trzeciej już generacji feministek. Kolejny raz Arendt ,wciagnięta” zostaje przez feministki do swojego klubu. To pokolenie interpretuje Arendt, skupiając się na trzech ludzkich aktywnościach: pracy, wytwarzaniu i działaniu? ${ }^{7}$. W tym przypadku interesować nas będzie ostatnia-działanie. Choć dotyczy polityki, bo polityka jest działaniem, to w koncepcji Arendt, działanie powiązane jest z tzw. zdolnością narodzin (natality). Feministki przejmują tę myśl od Arendt, widząc w tym jednocześnie swój udział w polityce. To kobieta jest przecież tą, która rodzi człowieka, czyli tego, który będzie uczestniczył w przestrzeni publicznej. Przez co sama kobieta, choć pośrednio, w pewien sposób uczestniczy. Arendt jawi się tu jako feministka.

5 Zob. H. Arendt, Korzenie totalitaryzmu, thum. M. Szawiel, D. Grynberg, Wyd. Niezależna Oficyna Wydawnicza, Warszawa 1993, t. I, cz. I: Anty-semityzm, s. $35-160$.

${ }^{6}$ Zob. H. Arendt, Odpowiedź Hannah Arendt na list Gershoma Scholema, w: H. Arendt, Eichmann w Jerozolimie, tłum. A. Szostkiewicz, Wyd. Znak, Kraków 2004, s. 397.

7 Arendt omawia osobno te trzy ludzkie aktywności w poszczególnych rozdziałach Kondycji ludzkiej. Zob. H. Arendt, Kondycja..., rozdział III: Praca, s. 87-149, rozdział IV: Wytwarzanie, s. 151-192, rozdział V: Działanie, s. 193-268. 
Widzimy więc, że w przedstawionym przez Young-Bruehl zarysie historycznym Arendt, jeśli jest akceptowana przez feministki, to tylko dlatego, iż podtrzymuje dualistyczną wizję świata. Feministki, które uznają niemiecką filozof za propagatorkę „feministycznej” wizji świata, robią to tylko ze względu na fakt, że Arendt zachowuje podział na prywatne i publiczne. Prywatne znaczy dla nich „kobiece”. Uznają one, że po pierwsze, dla autorki Kondycji prywatne również znaczy „kobiece”. Po drugie, dla nich prywatna sfera jest wartościowsza od publicznej-męskiej. Tutaj nie zgadzają się więc z Arendt, dla której polityka jest, można powiedzieć, sensem życia każdego człowieka. W kolejnych paragrafach artykułu zobaczymy jak, w rzeczywistości, widzi ten problem Arendt. Zanim jednak przejdziemy do wyjaśniania zagadnienia prywatności dowiedzmy się dlaczego jest ona jednak, w większym stopniu, uznawana za anty-feministkę niż feministkę. Oczywiście i w tym przypadku w centrum zainteresowania znajdzie się arendtowski podział świata.

\section{Arendt jako anty-feministka}

Niemiecka filozof jednak, przede wszystkim, uznawana jest ze przeciwniczkę feminizmu. Jedna z feministycznych komentatorek pism Arendt pisze o Kondycji ludzkiej: ,,ucieleśnienie tragedii kobiecego umysłu, którą ożywiła męska ideologia"8. W tym paragrafie przedstawię te poglądy, które odczytują arendtowską teorię polityki jako atak na kobiety i uznają Arendt za anty-feministkę.

Do takich komentatorek - feministek należy Maria Markus ${ }^{9}$. W kontekście teorii Arendt konstruuje ona trzy pytania ${ }^{10}$. Pierwsze dotyczy problemu „różnicy”, drugie odnosi się do pojęcia „świadomego pariasa”, trzecie natomiast jest pytaniem o tzw. ,problem kobiet”. Rezultatem tych rozważań jest stwierdzenie o anty-feministycznym charakterze filozofii Arendt.

Problem „różnicy” powiązany jest z pojęciem natality. Markus podobnie jak Young-Bruehl, używa tego pojęcia w kontekście fizycznych narodzin, i mówi tutaj o fizycznym fakcie narodzin kobietą czy mężczyzną. Nie da się pokonać natality, jednak sam fakt urodzenia się kobietą czy męż-

8 Adrienne Rich za E. Young-Bruehl, Hannah..., s. 312.

9 Zob. M. Markus, The 'Anty-feminism'..., s. 119-129.

10 Ibidem, s. 120. 
czyzną nie determinuje człowieka, jego osobowości. Urodzenie nie wyczerpuje naszej jednostkowości. Arendt bowiem pyta o człowieka: nie czym jest, ale kim jesteś ${ }^{11}$. W ten sposób, można powiedzieć, pluralizuje ona człowieka, czyni go różnym od sąsiada. Jak wiemy, różnorodność jest podstawą działania. Według Arendt każdy człowiek, który działa jest inny, jest sobą i pojawia się w przestrzeni publicznej właśnie taki jaki jest naprawdę. Jego indywidualności nie determinuje jednak płeć, twierdzi Arendt i dlatego właśnie uznana jest za anty-feministkę, gdyż pomija rolę płci.

Drugim zagadnieniem, w kontekście anty-feminizmu Arendt, który Markus porusza, to problem ,świadomego pariasa". Arendt pisze o nim w Korzeniach totalitaryzmu ${ }^{12}$. Choć pojęcie pariasa i parweniusza używa Arendt analizując anty-semityzm, i choć bezpośrednio opisuje ona sytuację Żydów, „to świadomy parias” znaczy ogólnie osobę, która pozostaje tym kim jest, bez względu na kontekst ${ }^{13}$. Takim ,świadomym pariasem” jest, według Arendt, Rahel Varnhagen i Rosa Luxemburg. To kobiety, które są po prostu soba, i dlatego są wyjątkowe, ale nie wyjątkowe jako kobiety, lecz wyjątkowe jako ludzie, którzy akceptują to, kim są bez względu na okoliczności. Arendt, pisze Markus, odmówiła objęcia posady profesora na Uniwersytecie Princeton, ponieważ zaoferowano jej tę posadę uznając ją za „wyjątkową kobiete" ${ }^{\text {. }}$. Arendt nie chciała być jednak nazywana wyjątkową kobietą, chciała być wyjątkowa ze względu na to kim jest. Pozostać sobą zawsze i wszędzie znaczy być „świadomym pariasem”, a przeto, być wyjątkowym człowiekiem. Więc i w tym przypadku Arendt pomija znaczenie płci. Bycie sobą jest poza podziałem na płeć.

W ostatnim punkcie Markus przechodzi do omówienia tzw. ,problemu kobiet" ${ }^{\prime 15}$. Arendt, zdaniem Markus, porusza go omawiając postać Rahel Varnhagen, zasymilowanej Żydówki. Na czym polega ten problem? Pojawia się on jako rozbieżność pomiędzy tym, czego mężczyzna oczekuje od kobiety i między tym, czego kobieta pragnie od mężczyzny. W rezultacie, mówiąc o problemie kobiet, musimy odwołać się do potrzeb, stwierdza Markus. „Problem kobiet” jest bowiem pytaniem o potrzeby kobiet. To wokół nich toczy się debata. zdaniem Arendt, zbędna. Potrzeby nie są bo-

11 Ibidem, s. 121-122.

12 H. Arendt, Korzenie..., t. I, s. 95-118.

13 M. Markus, The 'Anty-feminism'..., s. 122-125.

14 Ibidem, s. 122.

15 Ibidem, s. 125-129. 
wiem tematem publicznym, to prywatna sprawa każdej jednostki. To, czego pragnę, nie interesuje świata. Potrzeby są niepolityczną sprawą, lecz prywatną. Arendt sprzeciwia się mieszaniu dwóch sfer. Doszło do tego w nowożytności i zakończyło tragedią, bo utratą wolności ${ }^{16}$. Arendt przyjmuje więc pewne założenie, które jest jednym z powodów jej niechęci do tzw. sprawy kobiet. Tym punktem wyjścia jest teza, że istnieją dwa światy: prywatny i publiczny, i że jest między nimi przepaść, która musi zostać zachowana, aby mogła istnieć sfera wolności - polityka.

Te trzy problemy przedstawione przez Markus sprowadzają się w rezultacie do jednego - Markus zarzuca Arendt, że nie podkreśla ona roli płci, ale nie płci w ogóle tylko płci żeńskiej. Ma pretensje do autorki Kon$d y c j i$, że wyklucza ona poza obszar polityki problemy kobiet. Jednocześnie Markus dostrzega w teorii Arendt sprzeczność. Gdyż, jej zdaniem, niemiecka filozofka zarazem neguje udział kobiet w polityce, jednocześnie popierając ich walkę o równe prawa obywatelskie. Musimy jednak pamiętać, że według Arendt wyzwolenie i wolność nie są tym samym ${ }^{17}$. Mając świadomość tej różnicy teoria Arendt zdaje się być bardziej klarowna. Wyzwolenie jest jedynie warunkiem - biletem wstępu do przestrzeni publicznej. Wyzwolenie poprzedza wolność, ale nią nie jest. To podstawowy krok na drodze ku wolności ${ }^{18}$. Kobiety walcząc o prawa obywatelskie, czyli, o prawo bycia obywatelem, walczą o wyzwolenie. One

16 Arendt pisze o tym w książce $O$ rewolucji. Wydarzeniem, które doprowadziło do połączenia się dwóch sfer była Rewolucja Francuska. Zob. H. Arendt, O rewolucji, thum. M. Godyń, Wyd. Kraków: X: Totus 1991.

17 Zob. H. Arendt, Czym jest wolność, w: H. Arendt, Między czasem minionym a przyszłym. Osiem ćwiczeń z myśli politycznej, thum, M. Godyń, W. Madej, Wyd. ALETHEIA, Warszawa 1994, s. 175-208.

18 Agnes Heller, węgierska filozof, wymienia, obok wyzwolenia i wolności, emancypację. To, według niej, trzy oddzielne procesy. W przeciwieństwie więc do Arendt emancypacja kobiet nie oznacza tutaj ich wyzwolenia. „Emancypacja oznacza doprowadzenie do zaakceptowania przez ogół obywateli pewnej grupy ludzi, która przedtem nie była akceptowana. Emancypacja w Europie odbywała się w trzech falach. Były to: emancypacja klasy pracującej, emancypacja Żydów i emancypacja kobiet. [...] emancypacja to problem dotyczący 'wchłonięcia' danej kategorii osób w ramy konkretnego społeczeństwa, a więc przyznanie im takich samych praw obywatelskich, jakie posiadają pozostali członkowie danej społeczności. Wyzwolenie jest czymś innym. Znamy wiele przykładów wyzwolenia. Ktoś może być na przykład wyzwolony od tyranii. [...] Wydaje mi się, że możemy je w pewnym stopniu porównać z uzyskaniem niezależności”. Zob. A. Heller, Wykłady i seminarium lubelskie, tłum, W. Bulira i inni, praca w przygotowaniu do druku przez Wyd. UMCS. 
nie działają jeszcze, lecz tylko otrzymują podstawowe prawo, które umożliwi im działanie.

Kolejną, choć bardziej radykalna, feministką krytykującą teorię Arendt jest Mary O’Brien. Oskarża ona Arendt o podtrzymanie, dominującego w filozofii, „męskiego strumienia” („,male - stream”) myśli ${ }^{19}$. Arendt jawi się jej jako kontynuatorka tradycji filozoficznej. Powodem jest właśnie owa dystynkcja. W świecie polis podział ten oznaczał rozróżnienie na kobiety i niewolników z jednej strony oraz na mężczyzn, czyli wolnych obywateli, z drugiej. Arendt przejęła od starożytnych ów podział na prywatne i publiczne, co zostało odebrane, głównie przez feministki, jako zgoda na zniewalanie kobiet i jako poparcie męskiej dominacji. Arendt ,akceptuje normalność, a nawet konieczność męskiej dominacji, i ...wierzy, że funkcje i struktury właściwe dla sfery prywatnej rozwijały się historycznie w sposób, który niemal zniszczył publiczne królestwo"20, pisze O’Brien. Rozróżnienie na prywatne i publiczne, zostało dokonane, zdaniem O’Brien, przez mężczyzn jako ucieczka przed ciężarem reprodukcji. Zamykając kobiety w domu i, tym samym, na nie przenosząc obowiązki rodzicielskie, mogli teraz cieszyć się wyższym sposobem egzystencji. Wolni z trosk o przetrwanie mogli stać się obywatelami czerpiącymi radość z politycznego działania. Gdy Arendt uznała „męski podział” za aksjomat swojej teorii, stała się kobietą popierającą męski punkt widzenia. Narzuciła role społeczne: mężczyzna jako wolny obywatel świata działa w świecie wolności, kobieta zniewolona biologią, przymusem reprodukcji, odcięta od świata „greckim murem” skazana jest na wieczną samotność domu. Jej przeznaczeniem jest utrzymanie gospodarstwa i rodzenie potomków wolnych ludzi. Kobietą rządzi przymus, mężczyzna jest wolny.

Zdaniem O'Brien ,grecki podział” jest tworem sztucznym i należy go zniszczyć. Jest wymierzony przeciwko kobiecie - jej wolności. Jest poparciem męskiego sposobu patrzenia na rzeczywistość, który cechował całą zachodnią tradycję filozoficzną.

Podobnie postrzega koncepcję Arendt Shiraz Dossa, gdy analizuje przestrzeń publiczną w kontekście Arendt ${ }^{21}$. Oczywiście problem kobiet pojawia się przy omawianiu arendtowskiej dystynkcji. W ujęciu Dossy jest to dystynkcja pomiędzy naturą a polityką, co w rzeczywistości ozna-

19 Zob. P. Hansen, Hannah Arendt..., s. 80-85.

20 M. O'Brien za P. Hansen, Hannah Arendt..., s. 81.

21 Zob. S. Dossa, The public realm and the public self. The political theory of Hannah Arendt, Wilfrid Laurier University Press, Waterloo 1989, s. 65-69. 
cza podział na prywatne i publiczne. Dossa chce w ten sposób podkreślić ścisłe powiązanie prywatnej sfery z naturą człowieka. W koncepcji Arendt, jak wiemy, prywatność odzwierciedla zwierzęcą naturę istot ludzkich. Błąd Dossy polega jednak na tym, że postrzega ona kobietę wyłącznie przez jej zwierzęcość, podobnie jak starożytni Grecy, czyli umiejscawia ją w domu i twierdzi, że tak to widzi również Arendt. Błąd Dossy ma podwójne podłoże. Po pierwsze, wynika on z braku rozróżnienia na to, co twierdzili obywatele polis, i na to, co twierdzi Arendt. Nie można utożsamiać poglądów Arendt z poglądami starożytnych, o ile nie robi tego sama zainteresowana. Po drugie, podobnie jak O'Brien, Dossa nie potrafi patrzeć na kobietę poza kategorią cielesności.

Ostatni głos w sprawie arendtowskiej dychotomii należy do Seyli Benhabib. Jest on bardzo zbliżony do poprzednich stanowisk. Benhabib również krytykuje podział na prywatne i publiczne. Nazywa ona model polityki Arendt agonistyczną koncepcją przestrzeni publicznej i odróżnia ją od modelu asocjacyjnego ${ }^{22}$. Model agonistyczny nawiązuje, jej zdaniem, do modelu polis, który zakładał istnienie podziału świata. Dystynkcja była, jak wiemy, warunkiem istnienia polis. W koncepcji Arendt nie brak odwoływań do starożytności, czego dowodem jest dokonane przez nią rozróżnienie na prywatne i publiczne. Według Benhabib, Arendt w swoim odwoływaniu się do modelu polis, zaniedbała bardzo ważną kwestię: ,jeśli agonistyczna przestrzeń publiczna polis mogła istnieć tylko dlatego, że były z niej wykluczone wielkie grupy istot ludzkich - takich jak kobiety, niewolnicy, dzieci, robotnicy, metojkowie oraz wszyscy nie-Grecy, których praca w zakresie powszednich konieczności życia umożliwiała nielicznym korzystanie z 'wolnego czasu na politykę', to czy krytyka wyłonienia się sfery społecznej, któremu towarzyszyła emancypacja wspomnianych grup z 'cienistego wnętrza gospodarstwa domowego' i ich wkroczenie w życie publiczne, jest zarazem krytyką politycznego uniwersalizmu ${ }^{23}$, pyta Benhabib. Jej argumentacja opiera się na krytyce elitarnego charakteru polis. Wyłonienie sfery społecznej oznacza dla niej, wbrew temu co twierdzi Arendt, zmianę z elitarnego charakteru polityki na egalitarny, czyli dostępny każdemu. Wyłonienie się sfery społecznej pokazuje jak w czasie pewne grupy, w tym kobiety, uzyskały prawa polityczne. Powstanie tej przestrzeni jest więc, dla Benhabib, czymś pozy-

22 Zob. S. Benhabib, Trzy modele przestrzeni publicznej, „Krytyka polityczna” nr 3, s. 75-79.

${ }^{23}$ Ibidem, s. 75-76. 
tywnym. Oznacza dla niej, że teraz każdy może działać w polityce. Negatywne podejście Arendt do sfery społecznej, czyli rezultatu przedostawania się do przestrzeni publicznej tzw. kwestii socjalnej, jest więc jednocześnie, zdaniem Benhabib, zgodą na to, by pewne grupy nie miały dostępu do wolności, np. kobiety.

Agonistyczny model polityki, który reprezentuje Arendt, jest więc elitarny, natomiast powstanie społeczeństwa, twierdzi Benhabib, jest przejawem egalitarnego charakteru polityki. Jeśli Arendt neguje powstanie społeczeństwa, to neguje również udział pewnych grup, w tym kobiet, w przestrzeni publicznej.

\section{Dlaczego Arendt nie jest ani feministką, ani anty-feministką?}

Twierdzę, że Arendt nie jest ani feministką, ani anty-feministką. Zgadzam się więc ze stanowiskiem Mary Dietz ${ }^{24}$, która odwołując się do trzech aktywności ludzkich wyróżnionych przez Arendt twierdzi, że płeć ma u tej autorki znaczenie jedynie w odniesieniu do pracy (labor) i wytwarzania (work), czyli przedpolitycznych aktywności. To znaczy, że można dyskutować o roli płci, odwołując się tylko do tych kategorii, wówczas praca przynależy kobiecie i jest ona animal laborans, wytwarzanie jest zaś domeną męska, mężczyzna jest wówczas homo faber. Działanie natomiast znajduje się poza płcią. Jej zdaniem tę aktywność Arendt wynosi poza problem płci - poza fizyczność, i poza podział na kobietę i mężczyznę.

W tej części artykułu ustosunkuję się do powyższych stanowisk, próbując wykazać, że teoria Arendt wykracza poza feminizm i anty-feminizm. W pierwszej kolejności odniosę się do stanowiska Young-Bruehl, następnie do Markus oraz O'Brien i Benhabib.

Powracając do zarysu historycznego przedstawionego przez Young-Bruehl, na tle którego Arendt jawi się jako feministka, spróbujemy zanegować ten obraz autorki Kondycji. Nie twierdzę tutaj, iż Arendt uznano za „prawdziwą” feministkę, lecz twierdzę, że, w pewnym stopniu, niektóre wątki jej teorii feministki wykorzystywały na swoją korzyść. Sama Young-Bruehl stwierdza, że ani feministki nie mówiły o niej „,feministka", ani też sama Arendt nie używała takiego sformułowania. Mówiąc, że Arendt jest uważana za feministkę, chcę podkreślić, iż jej teoria była

24 E. Young-Bruehl, Hannah..., s. 315-316. 
przez niektóre feministki odbierana pozytywnie, o czym wiemy już z pierwszej części artykułu. Chcę wykazać jednak, że niesłusznie. Arendt nie miała nic wspólnego $\mathrm{z}$ feminizmem.

Rozważając problem feminizmu w filozofii Arendt Young-Bruehl dostrzega trzy główne problemy ${ }^{25}$. Pierwszy dotyczy tzw. feministycznej kultury. Zakładała ona istnienie jakiegoś, „wspólnego zmysłu kobiecego”. Według tej teorii istnieje kobiece myślenie. Wszystkie kobiety myślą podobnie. Arendt podważa ten pogląd. Jej praca wykazuje, że takie ujęcie kobiety jest zbyt ogólne. Bycie kobietą może mieć bowiem dla kogoś znaczenie, albo nie mieć żadnego. W teorii Arendt myślenie nie jest zdeterminowane płcią. Kiedy przybliża ona postać Raheli Varnhagen, nie podejmuje w ten sposób problemu płci, czy też zagadnienia anty-semityzmu, lecz przede wszystkim mówi o problemie bycia sobą. Każdy jest inny. Człowiek musi więc zaakceptować swoją różnicę, ale nie bycie kobietą, czy Żydem, ale bycie po prostu człowiekiem ${ }^{26}$. Pluralizm, który jest istotą polityki odnosi się do różnicy zawierającej się w samej definicji człowieka. W przestrzeni publicznej, każda różnica musi być respektowana, ale nie różnica płci, ale różnica osobowości.

Drugi problem pojawia się w związku z pojęciem opresji ${ }^{27}$. Żydzi bronią się przed opresją anty-semityzmu tak jak feminizm broni się przed opresją seksizmu. Arendt nie staje jednak w obronie kobiet. W Korzeniach totalitaryzmu porusza ona bardzo ważny problem dotyczący grupy opresjonowanej, ale nie są to z pewnością kobiety. Arendt próbuje odnaleźć korzenie anty-semityzmu, więc grupą, którą reprezentuje stanowią Żydzi. Błędem jest więc twierdzenie, że Arendt porusza problem feminizmu. Filozofka wyraźnie odnosi się do sytuacji Żydów, nie kobiet. Oczywiste jest natomiast, że antysemityzm nie jest tym samym, co seksizm, stwierdza Young-Bruehl. Dlatego, nie można powiedzieć, że Arendt rozumie sytuację kobiet, bo analizuje i walczy z antysemityzmem. Arendt krytykuje antysemityzm, nie zajmuje się zaś problemem seksizmu.

Uwaga ta odnosi się jednocześnie do trzeciego problem w kontekście „feminizmu” Arendt. Każde uprzedzenie, a jest ich, według autorki artykułu, trzy rodzaje: obsesyjne, histeryczne i narcystyczne, posiada specy-

${ }^{25}$ Zob. E. Young-Bruehl, Hannah..., s. 316-322.

${ }^{26}$ Zob. ibidem, s. 317. Arendt opisuje fenomen myślenia w książce: Myślenie. Zob. H. Arendt, Myślenie, tłum. H. Buczyńska-Garewicz, Wyd. Czytelnik, Warszawa 1991.

27 E. Young-Bruehl, Hannah..., s. 318. 
ficzny sens ${ }^{28}$. W feminizmie możemy mówić o uprzedzeniu narcystycznym, bowiem podkreślanie różnicy płci stanowi tu podstawę dyskusji. Dominuje więc w nim podział na prywatne/publiczne. Dla Arendt, która porusza problem anty-semityzmu nie feminizmu, jak wiemy, podział ten jest gwarantem istnienia publicznej wolności. Zburzenie granicy oddzielającej te dwa światy prowadzi do upadku sfery wolności. To stało się, zdaniem Arendt, podczas Rewolucji Francuskiej. Zburzono mur, oddzielając dwie sfery. „Odkąd bowiem rewolucja otworzyła biednym wrota do królestwa polityki, królestwo to stało się dziedziną prawdziwie 'socjalną'. Przytłoczyły ją troski i zmartwienia, które w rzeczywistości należały do sfery gospodarki" ${ }^{29}$. Przedostanie się tzw. kwestii socjalnej do sfery publicznej doprowadziło więc do jej upadku. Polityka stała się areną żądań. „Nieszczęśliwi' chcieli bowiem chleba, a wołanie o chleb zawsze będzie wydane jednym głosem. W tej mierze, w jakiej wszyscy potrzebujemy chleba, istotnie wszyscy jesteśmy tym samym i możemy zjednoczyć się w jedno ciało”, pisze Arendt ${ }^{30}$. Rewolucja Francuska, burząc grecką granicę, doprowadziła do upadku polityki. „Ocean nędzy i ocean wzbudzonych przez nędzę sentymentów połączyły się razem, by zatopić ustanowienie wolności”’31. To jest również konsekwencja totalitaryzmu - brak wolności. Gdy mowa więc o anty-semityzmie, uznanie dychotomii świata jest istotne, gdyż dystynkcja ta jest zaporą przeciwko totalitaryzmowi i w tym kontekście mówiła o niej Arendt.

Pozostaje nam odnieść się jeszcze do problemu natality. Interpretacja zdolności narodzin przez feministki nie jest w pełni poprawna. Zdolność narodzin umożliwia działanie, lecz natality nie odnosi się jedynie do fizycznych narodzin, nie stanowi pochwały macierzyństwa. Autorce Kondycji ludzkiej, chodzi głównie o tzw. „nowy początek” - powstawanie nowych idei, opinii, pomysłów. Człowiek, zdaniem Arendt, nie rodzi się raz, rodzi się przez całe życie ${ }^{32}$. Narodziny oczywiście odnoszą się do biologicznego przychodzenia na świat, lecz przed wszystkim oznaczają dla Arendt działanie. Zdolność narodzin jest zdolnością działania. Działać znaczy rozpoczynać coś, czego jeszcze na świecie nie było. Kobiety jako

28 Zob. ibidem.

29 H. Arendt, O rewolucji..., s. 91.

30 Ibidem, s. 94.

31 Ibidem, s. 95.

32 Zob. H. Arendt, Kondycja..., s. 193-198. 
rodzicielki, nie odgrywają w teorii Arendt żadnego politycznego znaczenia. Jako rodzicielka kobieta ma znaczenie jedynie w sferze prywatnej.

Hannah Arendt nie może zostać uznana za zwolenniczkę feminizmu. Choć porusza ona istotne problemy tj. antysemityzm, czy problem pluralności ludzi, to nie odnosi się ona w żaden sposób do problemu feminizmu.

Lecz Arendt nie jest również przeciwnikiem feminizmu. Nie można więc powiedzieć o niej - anty-feministka, tak jak robią to Markus czy O’Brien. Arendt nie występuje przeciwko kobiecie, ale przeciwko podejmowaniu w sferze publicznej problemów sfery prywatnej, czyli problemów dotyczących przetrwania. Markus ma ,żal” do autorki Kondycji, że nie wywyższa ona problemów kobiet ponad problemy mężczyzn, że traktuje obie rodzaje płci na równi. Gdy mówi o trzech zagadnieniach w teorii Arendt, które są przejawem anty-feministycznego nastawienia tej autorki: czyli o problemie „różnicy”, „świadomego pariasa”, oraz „problemie kobiet" - to przede wszystkim chodzi jej o brak w nich pewnego elementu - podkreślania roli płci. Różnorodność znaczy bowiem dla Arendt różnorodność ludzi, nie płci. Działać mogą ludzie różni od siebie, lecz nie ludzie różni pod względem płci. Rozróżnienie na kobiety i mężczyzn ma znaczenie jedynie w świecie prywatnym. Brak natomiast takiej dystynkcji w polityce nie oznacza dominacji mężczyzny: po prostu, płeć w przestrzeni publicznej nie istnieje w ogóle. Różnica w przestrzeni publicznej dotyczy osobowości. Arendt nie determinuje człowieka faktem urodzenia. Jak wiemy odrzuca ona koncepcję natury. Dla niej nie istnieje coś takiego jak kobieca postawa, kobiecy styl pisania, czy bycie kobietą (posiadanie cech kobiety). Zdaniem Niemki nie istnieje coś takiego jak kobiecość czy męskość, nie istnieją oczywiście w świcie polityki, ale trzeba pamiętać, że dla Arendt nie ma wyższej wartości niż uczestnictwo w sprawach publicznych. Dom to tylko karta wstępu do prawdziwej rzeczywistości ludzkiej.

Zarówno problem ,świadomego pariasa” dotyczącego problemu bycia sobą, jak i tzw. ,problemu kobiet” wykracza poza kwestię płci. Zdaniem Markus ,problem kobiet” wymagający odwołania się do potrzeb kobiet jest przez Arendt zdegradowany do poziomu prywatnego. Gdyż, jak wiemy, potrzeby stanowią dla Arendt problem na płaszczyźnie prywatnej nie publicznej. Kobiety chcą ze swoimi potrzebami przedostać się do sfery publicznej - pragną zniszczyć tym samym ,grecką granicę”. W ten sposób powstaje sfera socjalna, która jest wypaczeniem polityki. Kobiety nie chcą więc być wolnymi obywatelami, powie Arendt. Nie chcą pokazać się światu kim są naprawdę. Lecz pragną tego samego. Bowiem potrzeby ujednolicają ludzi. Płeć ujednolica. Jako kobiety, czy jako mężczyźni po- 
trzebujemy tego samego, czyli potrzeby ujednolicają. Wszyscy potrzebujemy przecież chleba, mówi Arendt. Kobiety wychodząc w świat ze swoimi potrzebami ograniczają siebie. Przestają się różnić jako ludzie, a przecież różnorodność jest podstawą polityki.

Markus zarzuca Arendt niekonsekwencję. Z jednej strony bowiem Arendt krytykuje poruszanie spraw kobiet w sferze publicznej, zaś z drugiej strony popiera ruchy wyzwoleńcze kobiet, gdyż emancypacja oznacza dla niej przyznanie praw obywatelskich tej grupie, która dotąd ich nie posiadała. Arendt nie patrzy jednak na kobiety przez pryzmat płci. Jest to dla niej po prostu pewna grupa, która dotąd nie posiadała podstawowych praw ludzkich, podobnie jak Żydzi. Jej poparcie, wbrew temu co sądzi Markus, nie jest przejawem niekonsekwencji. Wręcz przeciwnie. Na poziomie wyzwolenia kobiety stanowią jedynie pewną grupę społeczną. Ważny jest fakt, że jest to grupa uciskana, a nie, że tworzą ją kobiety. To Arendt nie interesuje. Interesuje ją natomiast świat, w którym, według niej, każdy ma prawo uczestniczyć, bez względu na płeć. Problem pojawia się dopiero na poziomie wolności. Czym innym jest bowiem uzyskanie praw obywatelskich, a czym innym jest wykorzystanie tych praw jako narzędzie degradacji sfery publicznej. To dlatego Arendt sprzeciwia się, narzucanej przez kobiety, perspektywie. Widzą one w polityce jedynie narzędzie zaspokajania własnych potrzeb. Kobiety zdobyły prawa obywatelskie i na tym zakończyło się ich działanie. Nie wiedzą, co czynić dalej ze zdobytą wolnością. Chcą za to przenieść problemy sfery prywatnej do sfery wolności. Kobiety chcą narzucić światu własną perspektywę. To tak jakby świata nie zamieszkiwali ludzie, lecz same kobiety ${ }^{33}$.

Markus uznała Arendt za anty-feministkę, gdyż w swojej teorii polityki nie wywyższała ona kobiet ponad mężczyzn. Podobnie uczyniła Mary O'Brien. Dla niej Arendt jest anty-feministką, dlatego, iż postuluje zachowanie granicy pomiędzy publicznym i prywatnym. O’Brien rozumie przez ten postulat chęć utrwalenia podziału między mężczyzną i kobietą. Widzi w Arendt „wroga” kobiet. Problem polega jednak na tym, że niemiecka filozof, podtrzymując starożytny podział świata nie wymienia kto

33 W tym kontekście ciekawy jest pogląd Agnes Heller na problem emancypacji kobiet, która przez emancypację rozumie zmianę sposobu patrzenia. „Nie uważam, aby amerykańskie feministki były wyemancypowane, ponieważ wprowadzenie na uniwersytetach women's studies nie jest żadną emancypacją. Nie sądzę, aby odwrócenie przemocy prowadziło do emancypacji”. Zob. A. Heller, [Wywiad z Simonem Torneyem pt.] Myślenie samodzielne, „Przegląd Polityczny” 2001, nr 51, s. 60. 
będzie należał do każdej ze sfer. Zrobił to Arystoteles, lecz nie ona. Arendt powiedziała jedynie, że pierwsza ze sfer jest królestwem konieczności, druga zaś, wolności. To feministki postawiły znak równości pomiędzy sferą konieczności, czyli domem, a kobietą. Do czego zmierzam? Choć Arendt przywołuje pisma Stagiryta, gdy mówi o modelu polityki polis, to z całą pewnością, jak słusznie zauważył Hansen, odrzuca ona koncepcję natury ${ }^{34}$. Dla niej człowiekiem nie jest się z natury. W ogóle nie istnieje coś takiego jak natura ludzka ${ }^{35}$. To bardzo ważna uwaga przy omawianiu problemu 'feminizmu' u Arendt. Nie możemy nazwać Arendt antyfeministką dlatego, że odwołuje się ona do pism Stagiryty. Ona odrzuca tezę o rodzeniu się kobietą. Twierdzi natomiast, że zarówno mężczyzna jak i kobieta, czyli każdy człowiek, właśnie przez sam fakt bycia człowiekiem skazany jest na przebywanie w granicach domu. Pytanie brzmi tylko: jak długo?

„Było rzeczą oczywista, pisze Arendt, że podtrzymanie indywidualnego życia winno być zadaniem mężczyzny, a przetrwanie gatunku zadaniem kobiety, i obie te naturalne funkcje, praca mężczyzny związana z dostarczaniem pożywienia i praca kobiety rodzącej dzieci, były podporządkowane temu samemu naciskowi życia. Naturalna wspólnota w gospodarstwie domowym rodziła się zatem z konieczności i konieczność władała wszystkimi wykonywanymi w niej czynnościami"36. Różnica między kobietą a mężczyzną dla starożytnych Greków znaczy, że praca mężczyzny jako „zwierzęcia roboczego” może być zastępowalna przez niewolnika, a pracy kobiety, czyli rodzenie dzieci nie da się zastapić w żaden sposób ${ }^{37}$. Tym samym jest ona skazana na swój los i nikt nie może tego zmienić. Oznacza to, że kobieta nie posiada karty wstępu do polityki. Jest uwięziona w domu, gdyż jest kobietą. Dlatego jej los podobny jest do losu niewolnika, gdyż praca niewolnika, jak i praca kobiety ma charakter przymusowy.

Na pytanie: ile czasu człowiek powinien spędzać w domu?, odpowiedź starożytnych brzmiałaby: mężczyzna - tyle ile czasu potrzebuje on na odpoczynek, kobieta - całe życie. Takiej odpowiedzi udzieliliby jednak mieszkańcy polis, nie Arendt. To od każdego człowieka zależy, ile czasu

34 P. Hansen, Hannah Arendt..., s. 85.

35 H. Arendt, Korzenie..., s. 487.

36 H. Arendt, Kondycja..., s. 36.

37 N. Gładziuk, Cóż po Grekach. Archetyp polis w twórczości Hannah Arendt, Wyd. Warszawa: ISP PAN; Toruń: A. Marszałek 1991, s. 12-13. 
chce być tylko zwierzęciem, a ile chce on poświęcić na „prawdziwe” życie. Jak wiemy odrzuca ona koncepcje natury, dzięki czemu każdy człowiek, niezależnie od płci, może dokonywać wyborów. Nie jest zdeterminowany płcią. Wystarczy tylko chęć uczestnictwa i odwaga, gdyż działanie, według Arendt, nie jest czynnością łatwą ${ }^{38}$. Z przestrzeni konieczności może więc wydostać się każdy człowiek by zażyć w ten sposób powietrza prawdziwej wolności. Gdyż, powtórzę za Arendt raz jeszcze, każdy człowiek prowadzi podwójną egzystencję - raz jest mieszkańcem domu, a raz świata. Problem nie dotyczy tutaj płci, obywatelem może być bowiem mężczyzna i kobieta. Dylematem jest natomiast: co zrobić z naszą zwierzęcością? Bo jak słusznie zauważyła Margaret Canovan, Arendt mówiąc o prawdziwej polityce powraca do rzeczywistości, w której istniało niewolnictwo. Starożytni Grecy mogli cieszyć się wolnością działania, gdyż posiadali niewolników ${ }^{39}$. Czy możliwa jest zatem prawdziwa polityka w takiej rzeczywistości, w której każdy sam niesie ciężar swojego biologicznego przetrwania, w której każdy sam musi troszczyć się o chleb?

Widzimy więc, że to nie Arendt przypisuje kobiety do roli żon, rodzicielek, matek i gospodyń domowych. Robili to mieszkańcy polis, robił to Stagiryta, ale nie Arendt. W świecie współczesnym robią to same kobiety. Możemy oskarżyć starożytnych o brak wyobraźni, i o wiele innych ułomności, które wpłynęły na postrzeganie kobiet tylko w jednej perspektywie, w perspektywie ciała. Dziś jednak nie musimy kierować się tymi schematami, a mimo wszystko robimy to. O' Brien widzi potrzebę zniszczenia muru. Chce połączyć ze sobą świat konieczności ze światem wolności. Nie dostrzega jednak najważniejszego, że dziś kobieta ma wybór w jaki sposób chce żyć. Czy chce być matką i żoną, czy woli działać w polityce. Stoi więc przed podobnymi dylematami, przed jakimi staje mężczyzna. To nie Arendt zamyka więc kobietę w domu, gdy wprowadza podział na prywatne i publiczne, ale same kobiety. Niemka nie utożsamia sfery prywatnej z płcią żeńską. Mężczyzna też przecież posiada ciało. Chęć zburzenia ,greckiej granicy” nie oznacza dla Arendt uwolnieniem się od konieczności biologicznego życia, od związku z naturą, lecz jest chęcią przedostania się wraz z nią do świata publicznego, to dla Arendt oznacza koniec wolności.

38 H. Arendt, Kondycja..., s. 42.

39 M. Canovan, The Political Thought of Hannah Arendt, Methuen \& CO LTD, London 1974, s. 78. 
Pozostało nam jeszcze omówienie teorii Benhabib i jej koncepcji społeczeństwa. Przede wszystkim należy postawić tu pytanie: jak Arendt rozumie społeczeństwo? Czy krytykuje je, ponieważ należą do niego ludzie niegdyś nie posiadający praw obywatelskich? Czy może raczej, w swojej ocenie, kieruje się ona pobudkami tych nowo powstałych uczestników polityki, czyli robotników i kobiet? Narodziny społeczeństwa oznaczają dla niemieckiej filozof upadek polityki, gdyż wraz z nim przedostają się do sfery wolności sprawy dotyczące przetrwania, czyli konieczność. Nie chodzi więc o to kto może, a kto nie może działać, bowiem, zdaniem Arendt, każdy takie prawo posiada. Chodzi natomiast o temat publicznej dyskusji. Według Arendt przestrzeń publiczna nie może być narzędziem rozwiązywania grupowych czy jednostkowych interesów. Świat zamieszkują ludzie, a nie kobiety czy klasa robotnicza. To właśnie ma ona na myśli, gdy krytykuje sferę społeczną. Jeśli natomiast Benhabib twierdzi uparcie, że „,nowoczesna przestrzeń publiczna jest z istoty porowata; ani dostęp do niej, ani porządek odbywającej się w niej debaty nie mogą być z góry określone przez kryteria moralnej i politycznej jednorodności”,40 to z pewnością nie wzięła ona pod uwagę polityki większości krajów europejskich w tym Polski, gdzie głównym tematem debaty publicznej jest problem przetrwania: bezrobocie, opieka socjalna itp. ${ }^{41}$ „Utraconym skarbem” rewolucji nie jest wcale, wbrew temu co twierdzi Benhabib, „fakt, że w końcu wszyscy mogą brać udział w życiu publicznym [...], że kiedy ze wspólnego działania wyłania się wolność, nie można z góry określić tematu publicznej rozmowy" "42, lecz jest nim właśnie wolność. Arendt krytykuje Rewolucję Francuską i nazywa tą ,złą”, nie dlatego, że umożliwiła ona wkroczenie w przestrzeń publiczną pewnych grup społecznych, lecz dlatego, że stanowiła zapowiedź upadku polityki. Arendt nie krytykuje ludzi i nie odmawia im prawa uczestnictwa, krytykuje ich intencje. Ona twierdzi jedynie, że gdy pewne grupy wkraczają w politykę by wykorzy-

40 S. Benhabib, $\operatorname{Trz} y \ldots$, s. 78.

${ }^{41} \mathrm{Z}$ takim stanowiskiem Arendt zgadzają się Agnes Heller i Ferenc Feher. Opisując ponowoczesnq kondycję politycznq stwierdzają oni, że współczesne partie polityczne zachodnich państw liberalno-demokratycznych stały się, „w ostatnich dekadach”, ,agencjami ekonomicznymi”. „W wyniku tego, wybory są ogniskowane, prawie bez wyjątku, na zagadnieniach ekonomicznych". W tym też sensie, węgierscy filozofowie mówią o redukowaniu „naturalnej” złożoności sfery publicznej. Zob. A. Heller, F. Feher, The Postmodern Political Condition, Polity Press and Blackwell Publisher, Cambridge-Oxford 1988, s. 10.

42 S. Benhabib, Trzy..., s. 78. 
stywać ją dla własnych celów, to nadejdzie taki dzień, gdy nie będzie już w czym uczestniczyć, nie będzie już świata. Problem polega bowiem na tym, że podział na przestrzeń prywatną i publiczną nie odnosi się do fizycznych granic. Rozróżnienia tego dokonuje Arendt na podstawie treści, a nie formy. Nie chodzi więc o to, kto należy do każdej ze sfer, ale jaki jest cel jego działania ${ }^{43}$. Celem mieszkańców domu jest przetrwanie, kierują się oni własnym interesem, celem przestrzeni prywatnej jest troska o wspólny świat.

Kto może pojawiać się w świecie? Każdy, kto tylko odważy się uczestniczyć, odpowiada filozofka. Sfera wolności jest otwarta dla wszystkich. Wystarczy tylko przekroczyć próg domu. Lecz nie jest to zadanie łatwe. Nie każdy chce być wolny, większość wybiera bezpieczeństwo domu, lecz tylko ci, którzy zdecydują się uczestniczyć staną się naprawdę ludzcy. Posługując się mocą perswazji, a nie mocą ręki tworzyć będą wspólny świat ludzi i tym samym staną się „nieśmiertelni”. Czas nie ma więc dla nich znaczenia. Ich życie jest dążeniem do szczęścia. Arystotelesowska eudaimonia jest celem, którego nikt nie osiagnie, a jedynie może do niego dążyć ${ }^{44}$. Ich los, w przeciwieństwie do mieszkańców domu, posiada sens, tym sensem jest troska o wspólny świat. Ludzie jako mieszkańcy świata, powtarza za Arystotelesem Arendt, prowadzą ,życie dobre”, jako domownicy żyją jedynie znojnie ${ }^{45}$.

Podsumowując: Zarówno dziedzina publiczna, jak i prywatna dotycza, choć w różnym stopniu, każdego człowieka. Ze sfery prywatnej nie można

43 Zob. Teoria „kuchennego stołu” Jeffa Goldfarba. Mówi ona o tym, że w momencie braku przestrzeni publicznej, sferę polityki zastępuje kuchenny stół, czyli inaczej przestrzeń prywatna. Tak np. było w rzeczywistości komunistycznej. Goldfarb daje przykład Polski komunistycznej. Wówczas sfera prywatna spełniała zadanie przestrzeni publicznej. W domu ludzie spotykali się i rozmawiali, natomiast w świecie (przestrzeni publicznej) rządziła przemoc i interesy. Co to oznacza? Arendtowski podział nadal jest zachowany, tylko, że w totalitaryzmie ludzie mogą naprawdę działać w ukryciu, w domu, i to on staje się wówczas sferą publiczną. Natomiast poza granicami domu rozciaga się sfera prywatna. Zatem dom i świat to jedynie metafory, których Arendt używa, by zobrazować sposób życia mieszkańców poszczególnych sfer. Dom i przestrzeń publiczna niekoniecznie odnoszą się do fizycznej przestrzeni. Gdy ówczesne teorie feministyczne nawoływały do porzucenia domu i wyjścia na świat, kobiety z bloku sowieckiego nie posłuchały ich przesłania. Na feminizm patrzyły negatywnie, gdyż nie chciały porzucać domu. To w nim bowiem mogły być naprawdę wolne. Zob.

J. Goldfarb, The Kitchen Table and Beyond, maszynopis.

44 H. Arendt, Kondycja..., s. 37.

45 Ibidem, s. 42-43, 212. 
zrezygnować w żaden sposób, nie można pominąć przecież zwierzęcości człowieka. Jednak o uczestnictwie w polityce decyduje już każdy z ludzi, bo działanie jest kwestią wyboru, a nie przymusu. W przeciwieństwie więc do gospodarstwa domowego, przestrzeń publiczna jest obszarem wolności. To ona jest, zdaniem Arendt, jedyną wartością i celem każdego człowieka. „Gospodarstwo domowe jest bowiem częścią państwa”46, ale tylko jako jego warunek nie fundament.

Linia graniczna, którą Gładziuk określa jako „cięcie zasadnicze”,47 leży pomiędzy dwoma biegunami, dwoma światami całkowicie odrębnymi od siebie. Arendt dzieli rzeczywistość ludzką, by w ten sposób możliwe było działanie. Oddziela od siebie konieczność i wolność, przemoc i moc słowa, nierówność i równość uczestnictwa, animal laborans i homo politicus, śmierć i nieśmiertelność, przestrzeń bezpieczeństwa i świat ryzyka. Niemiecka filozof dzieli świat na dwie rzeczywistości: przedpolityczną formę życia w gospodarstwie i polityczną przestrzeń wolności, a podział ten czyni, podobnie jak mieszkańcy polis, aksjomatycznym założeniem swojej filozofii. Aby istniała prawdziwa polityka, musi, zdaniem Arendt, istnieć rozróżnienie na dom i publikę. Dychotomia rzeczywistości jest warunkiem działania, a działanie, pamiętajmy, jest według filozofki, jedyną troską człowieka.

\section{Podsumowanie}

Arendt nie była jedną z feministek. Nie była też anty-feministką. Pomimo wszystko jej koncepcja wzbudziła zainteresowanie w środowiskach feministycznych. Dyskusja wśród feministek toczy się wokół arendtowskiego podziału na prywatne i publiczne. Feminizm odrzuca ten podział. Rozróżnienie na sferę gospodarstwa domowego i sferę polityki, uważa on za wynalazek mężczyzn, którzy chcieli, w ten sposób, zyskać więcej „wolnego czasu”. Uznanie tego podziału, co uczyniła Arendt, jest akceptacją tego, że mężczyzna jako istota lepsza, korzysta z wolności, kobieta zaś, nie mogąc uwolnić się od swojej cielesności, zdana jest na życie w domu. Arendt jednak akceptując starożytną dystynkcję nie zgadza się ze starożytnym poglądem na naturę ludzką. Podział na sferę publiczną

46 Arystoteles, Polityka..., s. 368 [1343].

47 N. Gładziuk, Cóż po Grekach..., s. 6. 
i prywatną nie oznacza podziału na mężczyzn i kobiety, lecz na wolność i konieczność.

Działanie - aktywność przynależąca do sfery wolności jest kwestią decyzji, nie rodzaju płci. To każda jednostka decyduje, niezależnie od tego czy jest mężczyzną, czy kobietą. W starożytnym polis takiego wyboru nie było, albo urodziłeś się jako wolny obywatel, albo urodziłeś się jako kobieta lub niewolnik ${ }^{48}$. Kobieta i niewolnik są mieszkańcami domu, obywatel - mężczyzna jest wolny i może działać. Lecz musimy jednak pamiętać, że tak widzieli to starożytni, nie Arendt. Ona nie określa, kto, do jakiej przestrzeni należy. Robią to feministki. Z jednej strony krytykują Arendt za podtrzymywanie tego podziału, jak O'Brien, z drugiej zaś mają ,żal” do niej, jak np. Markus, że nie podkreśla „problemów kobiet” i nie bierze pod uwagę ich potrzeb. W mojej opinii feminizm popada w sprzeczność. Zdaje się bowiem, że feministkom nie chodzi o to, by posiadać takie same prawa jak mężczyźni, ale by posiadać „lepsze” prawa właśnie ze względu na płeć, na bycie kobietą. Arendt pomijając rolę płci w dziedzinie polityki jest więc podejrzana o „współpracę” z mężczyznami.

Feministki mają dziś problem, ponieważ same tworzą to, z czym walczą. Chca, aby z jednej strony, patrzeć na nie tylko przez pryzmat kobiecości i chcą by podkreślać tę kobiecość. Z drugiej zaś strony, walczą ze stereotypowym poglądem na kobietę. Arendt nie robi tego - nie wyróżnia kobiety ze względu na płeć. W tym sensie Arendt nie jest feministką, ani anty-feministką. Nie porusza ona problemu płci w ogóle. Nie mówi ona:

48 Interesujące jest to, że feministki, mówiąc o arendtowskiej dystynkcji, poruszają jedynie problem kobiet. Przecież drugą grupa, będącą nawet w gorszej sytuacji niż starożytne kobiety, byli wówczas niewolnicy. Polis opierało się na ich pracy. Dziś już nie istnieją, ale potencjalnie takim niewolnikiem mógłby być każdy z nas, gdyby przyszło urodzić się w starożytności. Problem dystynkcji nie dotyczy w takim razie samych kobiet, niewolnikami byli przecież również mężczyźni. Dlaczego jedynie kobiety za niesprawiedliwy uważają arendtowski podział, a mężczyźni nie? Przecież oni również byli kiedyś wyłącznie mieszkańcami domu. Jeśli nastąpiła w czasie eliminacja niewolnictwa, to przecież i rola kobiet mogła ulec zmianie. Niewolników nie ma, kobiety są, ale przecież inne. Świat ciągle się zmienia. Zdaje się jakby feministki nie dostrzegały tego faktu i same narzucały sobie role społeczne. Po drugie, chcąc być konsekwentne, krytykując grecki podział, feministki powinny podjąć również problem niewolników, do których kiedyś należeli i mężczyźni i kobiety. Dostrzegłyby wówczas, że w starożytnym polis mieszkańcami domu były nie tylko kobiety, ale i płeć męska. Co z kolei oznacza, że problem w teorii Arendt, nie dotyczy płci. Można podważyć koncepcję Niemki ze względu np. na jej nierealny charakter, nie natomiast za dyskryminację kobiet. 
kobieta mieszka w domu, a mężczyzna w świecie - przestrzeni publicznej. Natomiast twierdzi: przestrzeń gospodarstwa jest sferą konieczności, zaś przestrzeń publiczna wolności. To, że kobiety same utożsamiają się ze swoim ciałem nie jest już winą autorki Kondycji ludzkiej. Każdy sam decyduje o sobie. W przestrzeni publicznej, mówi Arendt, działają ludzie, nie kobiety czy mężczyźni. Mary Dietz ma więc rację, gdy mówi, że na poziomie działania płeć traci znaczenie. Dotyczy to płci męskiej i żeńskiej. W teorii Arendt istnieje bowiem tylko jedna kategoria - obywatel. On nie posiada płci w ogóle. Kobietą lub mężczyzną można być w domu, nie na publicznym rynku. Nie można więc powiedzieć o Arendt, że jest feministą, ani też stwierdzić że jest anty-feministką. Arendt znajduje się poza tymi kategoriami, gdyż dla niej liczy się udział w polityce, nie płeć.

\section{Bibliografia}

\section{Prace Hannah Arendt:}

Arendt H., Czym jest wolność, w: H. Arendt, Między czasem minionym a przyszlym. Osiem ćwiczeń z myśli politycznej, thum. M. Godyń, W. Madej, Wyd. ALETHEIA, Warszawa 1994.

Arendt H., Kondycja ludzka, tlum. A. Łagodzka, Wyd. ALETHEIA, Warszawa 2000.

Arendt H., Korzenie totalitaryzmu, tłum. M. Szawiel, D. Grynberg, Wyd. Niezależna Oficyna Wydawnicza, Warszawa 1993, t. I.

Arendt H., Myślenie, tłum. H. Buczyńska-Garewicz, Wyd. Czytelnik, Warszawa 1991. Arendt H., O rewolucji, thum. M. Godyń, Wyd. Kraków: X: Totus, 1991.

Arendt H., Odpowiedź Hannah Arendt na list Gershoma Scholema, w: H. Arendt, Eichmann w Jerozolimie, tłum. A. Szostkiewicz, Wyd. Znak, Kraków 2004.

\section{Pozostałe pozycje:}

Arystoteles, Polityka z dodaniem pseudo-arystotelesowskiej ekonomiki, thum. L. Piotrowicz, PWN, 1964.

Benhabib S., Trzy modele przestrzeni publicznej, „Krytyka polityczna” nr 3, brak roku wydania.

Canovan M., The Political Thought of Hannah Arendt, Methuen \& CO LTD, London 1974.

Dossa S., The public realm and the public self. The political theory of Hannah Arendt, Wilfrid Laurier University Press, Waterloo 1989, s. 65-69.

Gładziuk N., Cóż po Grekach. Archetyp polis w twórczości Hannah Arendt, Wyd. Warszawa: ISP PAN; Toruń: A. Marszałek 1991. 
Goldfarb J., The Kitchen Table and Beyond, maszynopis.

Hansen P., Hannah Arendt. Politics, History and Citizenship, Polity Press, Cambridge 1993.

Heller A., [Wywiad z Simonem Torneyem pt.] Myślenie samodzielne, „Przegląd Polityczny" 2001, nr 51.

Heller A., Wykłady i seminarium lubelskie, tłum. W. Bulira i inni, praca w przygotowaniu do druku przez Wyd. UMCS.

Heller A., Feher F., The Postmodern Political Condition, Polity Press and Blackwell Publisher, Cambridge-Oxford 1988.

Young-Bruehl E., Hannah Arendt among Feminists, w: Hannah Arendt. Twenty Years Later, red. L. May, J. Kohn, The MIT Press, Cambridge-Massachusetts-London-England 1996, s. 307-323.

Markus M., The 'anti-feminism'of Hannah Arendt, w: Hannah Arendt. Thinking, Judging, Freedom, red. G. T. Kaplan, C. S. Kessler, Sydney, ALLEN \& UNWIN, Wellington-London-Boston 1989.

\section{Summary}

Feminists have a problem as they create themselves that which they fight against. On the one hand they demand that they are perceived through the perspective of femininity and they want to emphasize this femininity. On the other hand, though, they fight against a stereotypical feminine image. Arendt is different - she does not distinguish women because of their gender. In this sense Arendt is neither a feminist nor an ant-feminist. She does not touch upon the issue of gender at all. She does not claim that a woman lives at home whereas a man lives in the world, in the public space. Yet she does claim that the space of the household is the realm of necessity while the public space - that of freedom. In Arendt's opinion in the public space are operating people rather than men or women. Mary Dietz is therefore right in saying that gender loses significance at the operational level. This concerns both genders. In Arendt's theory there exists a single category - that of a citizen. A citizen has no gender at all. He or she can be a man or woman at home, and not in public. Therefore Arendt cannot be said to be a feminist or an anti-feminist. She falls beyond these categories as what counts for her is participation in politics, not gender. 